\title{
Performance of Primocane-fruiting Experimental Blackberry Cultivars in the Southern Appalachian Mountains
}

\author{
Gina E. Fernandez ${ }^{1}$ and James R. Ballington
}

AdDitional INDEX wORDs. Rubus, synthetic spun-bonded cover, polyester, polypropylene, production systems, season extension

SUMMARY. Yield performance of primocane-fruiting experimental blackberry

( $R u b u s$ spp.) cultivars from two breeding programs were evaluated in the southern Appalachian Mountains. The trial consisted of the nine experimental cultivars: NC 533, NC 534, NC 535, NC 537, NC 538, NC 539, APF-27, APF-46, and PrimeJim ${ }^{\circledR}$. In addition, rowcovers were applied to split plots in the spring to determine if harvest dates could be advanced. In 2007, five experimental cultivars had comparable high total yields (APF-27, APF-46, NC 535, NC 537, and NC 539), yet only three of these had comparable marketable yields (APF 27, APF-46, and NC 537). In 2008, APF-27 and APF-46 had significantly higher total yield (2234.5 and $2257.3 \mathrm{~g} /$ plant, respectively) and marketable yield (1611.2 and $1654.2 \mathrm{~g} /$ plant, respectively) than all other experimental cultivars. Rowcover treatments did not increase or decrease either total or marketable yield in any of the experimental cultivars in either year. In addition, rowcovers did not advance the date of $\mathbf{5 \%}$ or $\mathbf{5 0 \%}$ harvest in either year. On the basis of the conditions imposed in these studies, we determined that "APF" selections evaluated in this trial have higher second-year yield than "NC" selections, primocane-fruiting experimental cultivar yields are lower than yields commonly found with floricane-fruiting blackberries, and rowcovers as applied in this study are not a viable option for advancing harvest season of primocane-fruiting blackberries in the southern Appalachian Mountains.

$\mathrm{C}$ ommercial blackberry production is increasing in the southern and eastern United States (Strik et al., 2007). The majority of the production in this region is based on the use of floricane-fruiting cultivars, where fruiting occurs on second-year canes and the harvest season commences in June and ends in mid-August. In 1995, the University of Arkansas and North Carolina State University jointly released NC 194, a primocane-fruiting blackberry selection that was intended for use as parental germplasm (Ballington and Moore, 1995). Ten years later, the University of Arkansas released the first primocane-fruiting

\footnotetext{
Department of Horticultural Science, North Carolina State University, Box 7609, Raleigh, NC 27965

Research support provided in part by funds from the Golden LEAF Foundation.

We thank Tomas Moreno, Absalom Shank, and Larry Wohlers for their technical assistance.

Numbered experimental cultivars used in this study were tested in replicated yield trials from the North Carolina State University and University of Arkansas blackberry breeding programs. These selections were under evaluation at a number of locations to determine merits of each individual experimental cultivar. Therefore, experimental cultivars used in this study may or may not be available to the general public as a public cultivar release in the future.

${ }^{1}$ Corresponding author. E-mail: Gina_Fernandez@ncsu.
} edu.

cultivars Prime-Jim ${ }^{\circledR}$ and PrimeJan ${ }^{\circledR}$ (Clark et al., 2005). Although small in scope, the North Carolina State University blackberry breeding program continued to devote a portion of their resources to the breeding of primocane-fruiting blackberries since the release of NC 194 and have had several lines in observational trials in multiple locations in the state.

In North Carolina, we have observed low productivity when primocane-fruiting experimental cultivars from both breeding programs were grown in observational plots at research stations in the Piedmont region (elevation 300-400 ft). However, when primocane-fruiting experimental blackberry cultivars were grown in Mills River, NC (elevation 2000 ft), fruit production was much higher; both fruit size and number of fruit were greater than those observed in the Piedmont region. Although fruit production potential was much greater in the higher elevation, fall frosts often damaged fruit and ended the harvest season before the crop could reach its full potential (J.R. Ballington, personal communication). In Clarksville, AR, primocaneblackberries produce only a small amount of fruit in the late summer, likely as a result of lack of heat tolerance of the flowers (Clark, 2008; Stanton et al., 2007). However, when these same experimental cultivars were grown in Aurora, OR, harvest commenced in August and extended into October (Strik et al., 2008).

Season extension techniques are used to advance or delay the fruiting season of many small fruit crops including raspberry (Rubus idaeus) and blackberry (Pritts, 2008; Pritts et al., 1992; Strik and Thompson, 2009; Strik et al., 2008). When rowcovers were applied over the rows of primocanefruiting raspberries in the early spring before primocane emergence, fruit production occurred up to 3 weeks earlier than in rows without rowcovers. Strik et al. (2008) were able to advance bloom by $14 \mathrm{~d}$ when rowcovers were placed over dormant plots of primocane-fruiting experimental blackberry cultivars in Oregon. No studies have been conducted to evaluate the efficacy of rowcover use in promoting earlier fruiting in primocane-fruiting blackberries in the high elevations of the southern Appalachian region.

The objectives of this research were 2 -fold. First, we wanted to document yield of primocane-fruiting experimental blackberry cultivars from the North Carolina State University and University of Arkansas breeding programs in the southern Appalachian Mountains. Second, we wanted to examine the efficacy of rowcover use in promoting earlier fruiting and higher

\begin{tabular}{llll}
\hline $\begin{array}{l}\text { Units } \\
\begin{array}{l}\text { To convert U.S. to SI, } \\
\text { multiply by }\end{array}\end{array}$ & U.S. unit & SI unit & $\begin{array}{l}\text { To convert SI to U.S., } \\
\text { multiply by }\end{array}$ \\
\hline 0.4047 & $\mathrm{acre}(\mathrm{s})$ & $\mathrm{ha}$ & 2.4711 \\
0.3048 & $\mathrm{ft}$ & $\mathrm{m}$ & 3.2808 \\
2.54 & inch $(\mathrm{es})$ & $\mathrm{cm}$ & 0.3937 \\
1.1209 & $\mathrm{lb} / \mathrm{acre}$ & $\mathrm{kg} \cdot \mathrm{ha}^{-1}$ & 0.8922 \\
28.3495 & $\mathrm{Oz}$ & $\mathrm{g}$ & 0.0353 \\
33.9057 & $\mathrm{Oz} / \mathrm{yard}^{2}$ & $\mathrm{~g} \cdot \mathrm{m}^{-2}$ & 0.0295 \\
$\left({ }^{\circ} \mathrm{F}-32\right) \div 1.8$ & ${ }^{\circ} \mathrm{F}$ & ${ }^{\circ} \mathrm{C}$ & $\left(1.8 \times{ }^{\circ} \mathrm{C}\right)+32$
\end{tabular}


yields in nine primocane-fruiting experimental blackberry cultivars.

\section{Materials and methods}

This study was conducted at the Upper Mountain Research Center in Laurel Springs, NC (lat. $36^{\circ} 23^{\prime} 60^{\prime \prime} \mathrm{N}$, long. $86^{\circ} 17^{\prime} 24^{\prime \prime} \mathrm{W}$, elevation $867 \mathrm{~m}$; average last/first freeze date 19 Apr./ 15 Oct.). The soil was a Toxaway loam. The plants received standard recommended cultural practices for blackberries in this region, with the addition of rowcovers placed on plots in the spring as described below (Fernandez and Krewer, 2008). The plantings consisted of nine primocane-fruiting experimental cultivars (NC 533, NC 534, NC 535, NC 537, NC 538, NC 539, APF-27, APF-46) and the cultivar Prime-Jim ${ }^{\circledR}$. APF-27, APF-46, and 'Prime-Jim ${ }^{\circledR}$ ' were provided courtesy of the University of Arkansas. Plants were set in the field on 24 May 2006 into raised beds that were covered with black plastic. Plants were spaced at $4 \mathrm{ft}$ between plants and $10 \mathrm{ft}$ between rows. Plants were allowed to grow in the first year with minimal training and were pruned to the ground in December in all years of the study.

The experiment was a randomized complete block design with split plots. The experimental cultivar was the main plot, and presence or absence of rowcover $(+/-\mathrm{RC})$ was the split plot. Each split plot consisted of two plants. The treatment combinations were replicated four times. Plots were $20 \mathrm{ft}$ long, and each split plot was $10 \mathrm{ft}$ long. Spunbound polypropylene rowcovers [1.2 oz/yard ${ }^{2}$ (Typar®); Reemay, Old Hickory, TN)] were placed on the designated split plot on 3 Mar. 2007 and 1 Apr. in 2008, before primocane emergence. The rowcovers remained on the plots for $56 \mathrm{~d}$ in 2007 and $42 \mathrm{~d}$ in 2008. At this time, newly emerging canes were at least 6 inches tall. Cane heights were recorded on three dates in 2007. Plants were soft-tipped (removal of $0.75-2$ inches) in all plots when the majority of canes in a plot reached $1 \mathrm{~m}$. Soft-tipping occurred on a weekly basis for $\approx 3$ weeks in July depending on experimental cultivar; however, dates were not recorded.

Harvested fruit from each plot was separated into marketable and nonmarketable berries. Marketable berries were blemish free, weighed $5 \mathrm{~g}$ or greater, and did not have any visible deformities such as white drupelets.
Individual fruit weight was determined using berries randomly sampled before separating fruit into marketable and nonmarketable berries. Determination of the effects of experimental cultivar and rowcover on yield parameters was analyzed statistically as a split-plot design with four replications using appropriate analysis of variance procedures (SAS version 9.1; SAS Institute, Cary, NC). Means were separated using Fisher's protected least significant difference at $P \leq 0.05$.

\section{Results and discussion}

Year, experimental cultivar, and the interaction between the two variables had significant effect on total yield, marketable yield, and fruit weight. Therefore, data for the 2 years (consecutive) could not be combined (Table 1). Total and marketable yield was lower in most experimental cultivars in 2007 than in 2008 (Table 2). This yearto-year difference could be due to heat stress or age of the planting. Previous research has shown that heat stress could result in this type of variability. Stanton et al. (2007) found that viability of floral parts (pollen germination and stigma receptivity) in primocanefruiting blackberry cultivars was reduced when temperatures exceeded $84^{\circ} \mathrm{F}$. Bloom commenced on 12 June 2007 and 24 June 2008 and lasted $\approx 3$ weeks for all of the experimental cultivars. The maximum daily temperatures during bloom were 86 to $87^{\circ} \mathrm{F}$ in June and July of both years (State Climate Office of North Carolina, 2010). Therefore, if damage from heat stress to flowers occurred during bloom, it likely occurred each year and had comparable negative effects on yield.

Although temperatures during bloom could have reduced yield, the age of the planting was more likely the major factor in lower yield in 2007. The plots in this study were established in 2006 and were harvested for the first time in 2007. We have found that firstyear yields from our floricane-fruiting blackberry trials are lower than those in subsequent years (Fernandez and Shank, 2010). Although we have not systematically harvested primocanefruiting blackberries in North Carolina before this study, we believe that yield in all primocane-fruiting production systems will be lower in the first year of harvest than in subsequent years.

In both years of this study, APF27 and APF-46 had the highest total yield among all the experimental cultivars evaluated in this trial (Table 2). Yields of the "NC" experimental cultivars were not consistent from year to year. Total yield of NC 537 and NC 539 were comparable to APF-27 and APF-46 in 2007. However, in 2008, none of the "NC" selections had yields comparable to the two "APF" selections. Total yields of APF-27 and APF46 in 2008 were 2234.5 and 2257.3 $\mathrm{g} /$ plant, respectively. Therefore, based on a plant density recommended for floricane-fruiting cultivars (Fernandez and Krewer, 2008) of 1090 plants/ acre, the potential total yield of APF27 and APF-46 would be $\approx 5622$ and $5413 \mathrm{lb} /$ acre, respectively. This yield is lower than 'Navaho', a floricanefruiting blackberry that has produced at least $8000 \mathrm{~g} /$ plant (Fernandez and

Table 1. Probability values from analysis of variance for year, experimental cultivar, with and without rowcovers, and interaction of total yield, marketable yield, and fruit size of nine primocane-fruiting experimental blackberry cultivars grown in 2 years (consecutive) in Laurel Springs, NC.

\begin{tabular}{lccc}
\hline & \multicolumn{3}{c}{ Probability } \\
\cline { 2 - 4 } Source & Total yield & Marketable yield & Mean fruit wt \\
\hline Year & 0.0001 & 0.0001 & 0.052 \\
Replication (year) & 0.5422 & 0.4895 & 0.0255 \\
Experimental cultivar & 0.0001 & 0.0001 & 0.0001 \\
Experimental cultivar $\times$ year & 0.0001 & 0.0001 & 0.0024 \\
Replication $\times$ experimental & 0.9993 & 0.996 & 0.8777 \\
$\quad$ cultivar $($ year) & 0.538 & & 0.489 \\
Rowcover & 0.4776 & 0.4477 & 0.2094 \\
Rowcover $\times$ experimental & & & 0.9228 \\
$\quad$ cultivar & 0.7239 & 0.796 & 0.0589 \\
Rowcover $\times$ year & 0.3552 & 0.2058 & \\
Rowcover $\times$ experimental & & & \\
$\quad$ cultivar $\times$ year & &
\end{tabular}


Table 2. Total yield, marketable yield, individual fruit weight, and $\mathbf{5 \%}$ and $\mathbf{5 0 \%}$ harvest dates of nine primocane-fruiting experimental blackberry cultivars in 2007 and 2008.

\begin{tabular}{|c|c|c|c|c|c|c|c|c|c|c|}
\hline \multirow{2}{*}{$\begin{array}{l}\text { Experimental } \\
\text { cultivar }\end{array}$} & \multicolumn{2}{|c|}{$\begin{array}{l}\text { Total yield } \\
\left(\mathrm{g} / \text { plant }^{\mathrm{z}}\right.\end{array}$} & \multicolumn{2}{|c|}{$\begin{array}{c}\text { Marketable yield } \\
(\mathrm{g} / \text { plant })\end{array}$} & \multicolumn{2}{|c|}{$\begin{array}{l}\text { Mean fruit } \\
\text { wt }(\mathrm{g})\end{array}$} & \multicolumn{2}{|c|}{ Date of $5 \%$ harvest } & \multicolumn{2}{|c|}{ Date of $50 \%$ harvest } \\
\hline & 2007 & 2008 & 2007 & 2008 & 2007 & 2008 & 2007 & 2008 & 2007 & 2008 \\
\hline $\mathrm{APF}$ & $827.5 . \mathrm{a}$ & $2257.3 \mathrm{a}$ & $667.0 \mathrm{ab}$ & $1654.2 \mathrm{a}$ & $6.1 \mathrm{~cd}$ & $6.1 \mathrm{c}$ & 7 Sept. ab & 28 Aug. a & 19 Sept. ab & 12 Sept. a \\
\hline NC 533 & $440.0 \mathrm{bc}$ & $1329.0 \mathrm{bc}$ & $298.7 \mathrm{~cd}$ & $690.6 \mathrm{~b}$ & $4.1 \mathrm{~d}$ & $4.9 \mathrm{de}$ & 7 Sept. a & 31 Aug. abc & 18 Sept. ab & 13 Sept. abc \\
\hline NC 534 & $70.5 \mathrm{~d}$ & $441.0 \mathrm{~d}$ & $59.1 \mathrm{e}$ & $262.0 \mathrm{c}$ & $3.1 \mathrm{~d}$ & $5.2 \mathrm{de}$ & 7 Sept. a & 7 Sept. d & 18 Sept. ab & 17 Sept. d \\
\hline NC 538 & $175.2 \mathrm{~cd}$ & $981.5 \mathrm{bcd}$ & $100.8 \mathrm{de}$ & $540.3 \mathrm{bc}$ & $3.7 \mathrm{~d}$ & $4.7 \mathrm{e}$ & 18 Sept. de & 2 Sept. bcd & 30 Sept. e & 19 Sept. bcd \\
\hline NC 539 & $822.7 \mathrm{a}$ & $446.1 \mathrm{~d}$ & $501.0 \mathrm{bc}$ & $237.7 c$ & $6.1 \mathrm{bc}$ & $5.3 \mathrm{~d}$ & 12 Sept. bc & 13 Sept. e & 25 Sept. d & 22 Sept. e \\
\hline Prime-Jim & $319.2 \mathrm{~cd}$ & $900.9 \mathrm{~cd}$ & $212.2 \mathrm{de}$ & $563.1 \mathrm{bc}$ & $7.6 \mathrm{a}$ & $6.8 \mathrm{~b}$ & 13 Sept. cd & 3 Sept. cd & 29 Sept. e & 25 Sept. cd \\
\hline
\end{tabular}

${ }^{\mathrm{z}} 1 \mathrm{~g}=0.0353 \mathrm{oz}$.

${ }^{y}$ Mean separation in columns by Fisher's protected least significance difference test at $P \leq 0.05$.

Shank, 2010). The highest yielding experimental cultivars from the North Carolina State University breeding program in 2008 were NC 533 (3187 $\mathrm{lb} / \mathrm{acre}$ ) and NC 535 (3629 lb/acre), which had total yields higher than 'Prime-Jim @ ${ }^{\circledR}$ ( $2160 \mathrm{lb} /$ acre $)$.

Marketable yields for most of the experimental cultivars were much lower than total yields (Table 2). The majority of the culled fruit was considered unmarketable (too soft to ship) and therefore unsuitable for commercial production. Strik and Thompson (2009) report that quality of fruit harvested from the floricane crop of 'Prime$\operatorname{Jim}{ }^{\circledR}$ ' and 'Prime-Jan ${ }^{\circledR}$ ' is lower than that of fruit harvested from other floricane-fruiting cultivars. Although no formal postharvest assessments of the "NC" experimental cultivars were conducted, notes from harvest indicate that the majority of the culled fruit was soft and therefore not marketable.

Fruit weight is an important component of yield potential in blackberries (Clark et al., 2007). Although much of the fruit was soft, the majority of the experimental cultivars had average fruit weight above $5 \mathrm{~g}$, which was considered a marketable size in this trial (Table 2). The experimental cultivars APF-27 and NC 535 had an average fruit weight of $7 \mathrm{~g}$ or more for both years of this study (Table 2). This fruit weight is comparable to the newly released 'Prime-Ark ${ }^{\circledR}$ 45' from the University of Arkansas (Clark, 2010).

Initial harvest dates changed in each year of this study; however, the order in which we started to harvest each experimental cultivar was, in general, consistent (Table 2). Harvest commenced in the first week of Sept. 2007 and the last week of Aug. 2008. APF27, APF-46, NC 533, and NC 534 were the earliest experimental cultivars and had comparable dates of $5 \%$ and $50 \%$ harvest in 2007 . Only the former three experimental cultivars had comparable harvest dates in 2008.

The placement of rowcovers on plots of primocane-fruiting blackberries at Laurel Springs, NC, in the spring did not increase total or marketable yield or fruit weight or advance the dates of $5 \%$ and $50 \%$ harvest (Table 3 ). In 2007, average cane height in plots with rowcovers was greater than for plots with no rowcovers on all dates before tipping (Fig. 1). Once the primocanes reached $1 \mathrm{~m}$, they were softtipped. Strik et al. (2008) found that canes that were tipped at $1 \mathrm{~m}$ produced higher yields than canes that were not tipped. The higher yields were attributed to the higher number of branches on each main cane. However, we did not experience the same increase in yield. In this study, all canes were tipped at the same height so that tipping occurred over 3 weeks starting in mid-July during the two growing seasons. Drake and Clark (2003) found that soft-tipping late in the season reduced yield of primocane-fruiting plants. Because canes in our study were tipped at the same height over 3 weeks in mid-summer, the tipping process may have negated any advantage in earliness and we may have experienced the same late season effect as experienced by Drake and Clark (2003).

This study was carried out at a site in the southern Appalachian Mountains, where the frost-free season is $\approx 144 \mathrm{~d}$ (State Climate Office of North Carolina, 2010). Temperatures of 31 and $28^{\circ} \mathrm{F}$ were recorded in the plots on 1 Oct. 2007 and 3 Oct. 2008, respectively. Although these temperatures were slightly below freezing temperature, the fruit remaining on the plants was severely damaged and had to be culled. A combination of high tunnels and rowcovers or heat blankets could help to extend the harvest season in the future. Both et al. (2007) were able to maintain temperatures $1-2{ }^{\circ} \mathrm{F}$ above outside temperatures in high tunnels using heat blankets. Alternatively, growers may be able to avoid early frosts by planting in a location that may have a slightly longer growing season. In the future, the new U.S. Department of Agriculture Plant Hardiness Zone Map may enable growers to decide where to plant a frost-sensitive crop. The new maps, which are based on geographic information system data, will be able to elucidate the effects of elevation increases and enclosure by mountainous terrain on a finer geographic scale (K. Kaplan, personal communication).

These are the first data collected on yield and season extension of primocane-fruiting experimental blackberry cultivars in the southern Appalachian Mountains. Primocane-fruiting experimental cultivars from North Carolina State University had yields that were comparable to the first generation of release from the University of Arkansas, such as 'Prime-Jim ${ }^{\circledR}$ '. The newer experimental cultivars, APF-27 and APF46 , had the highest total and marketable yields of all the materials evaluated in this trial. However, none of the experimental cultivars had yields comparable to those of floricane-fruiting cultivars. Previous reports showed that 


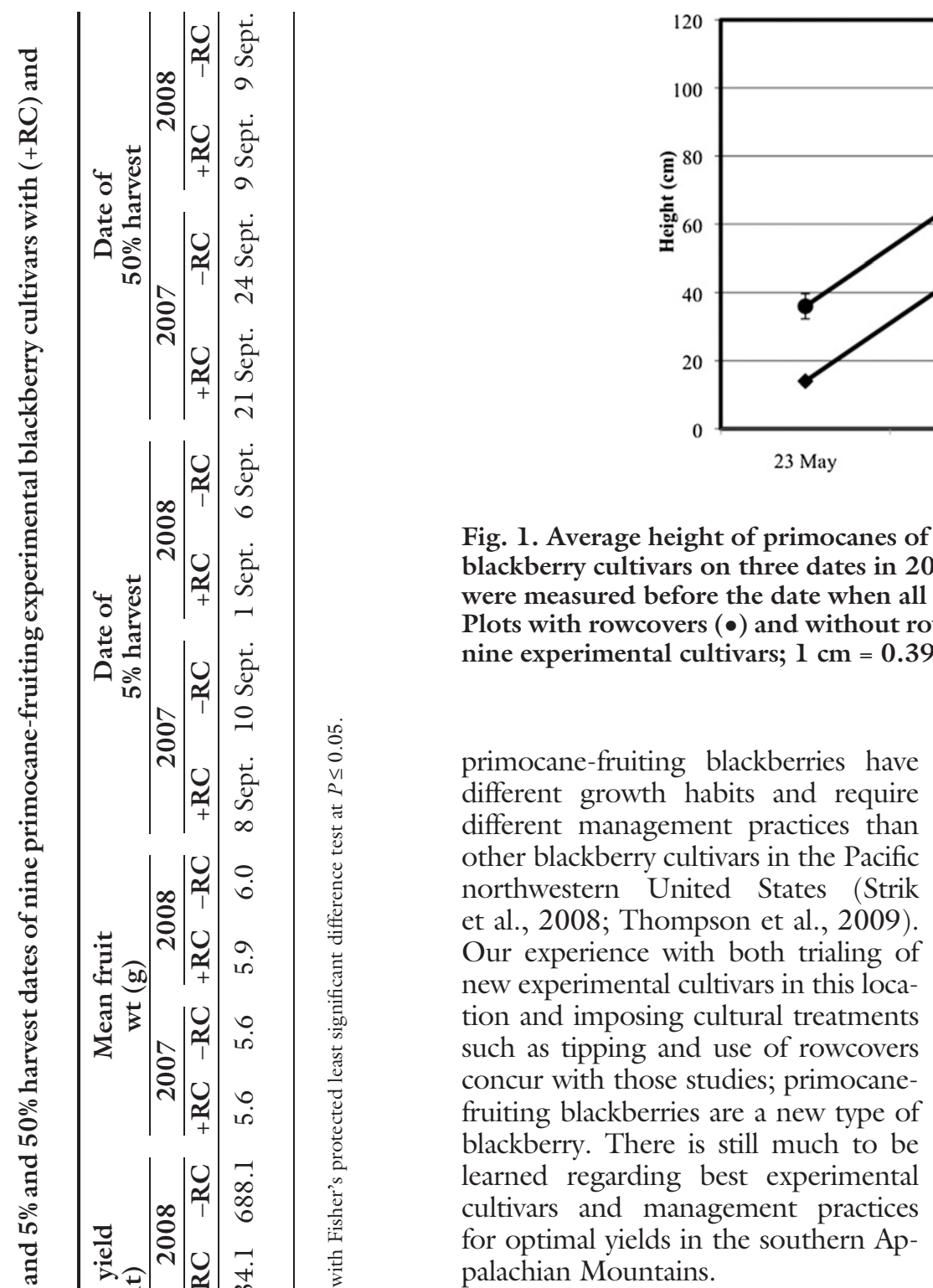

\section{Literature cited}

Ballington, J.R. and J.N. Moore. 1995. NC 194 primocane fruiting thorny erect tetraploid blackberry germplasm. Fruit Var. J. 49:101-102.

Both, A.J., E. Reiss, J.F. Sudal, K.E. Holmstrom, C.A. Wyenandt, W.L. Kline, and S.A. Garrison. 2007. Evaluation of a manual energy curtain for tomato production in high tunnels. HortTechnology 17:467-472.

Clark, J.R. 2008. Primocane-fruiting blackberry breeding. HortScience 43: 1636-1639.

Clark, J.R. 2010. Prime-Ark $45{ }^{\circledR}$, a new blackberry variety. Small Fruit News. 22 Sept. 2010. <http://www.smallfruits. org/Newsletter/Voll0-Issuel.pdf>.

Clark, J.R., J.N. Moore, J. Lopez-Medina, C. Finn, and P. Perkins-Veazie. 2005.
'Prime-Jan ${ }^{\circledR}$ ' and 'Prime-Jim ${ }^{\circledR}$ ' primocane-fruiting blackberries. HortScience 40:852-855.

Clark, J.R., E.T. Stafne, H.K. Hall, and C.E. Finn. 2007. Blackberry breeding and genetics. Plant Breed. Rev. 29:19144.

Drake, C.A. and J.R. Clark. 2003. Effects of pruning and cropping on field-grown primocane fruiting blackberries. HortScience 38:260-262.

Fernandez, G.E. and G. Krewer. 2008. 2008 Southeast Regional Bramble Production Guide. 22 Sept. 2010. <http://www. smallfruits.org/SmallFruitsRegGuide/ Guides/2008/08BrambleguideMay22. pdf>.

Fernandez, G. and A. Shank. 2010. Blackberry and raspberry harvest data 2008 and 2009. 22 Sept. 2010. <http://ncsu. edu/enterprises/blackberries-raspberries / production/latest-research/>.

Pritts, M., E. Hanson, J. Fiola, and M. Kelly. 1992. Rowcovers accelerate fruiting and increase productivity in primocanefruiting red raspberries. HortTechnology 2:46-51.

Pritts, M. 2008. Primocane-fruiting raspberry production. HortScience 43:16401641 .

Stanton, M.M., J.C. Scheerens, R.C. Funt, and J.R. Clark. 2007. Floral competence of primocane-fruiting blackberries Prime-Jan ${ }^{\circledR}$ and Prime-Jim ${ }^{\circledR}$ grown at three temperature regimes. HortScience 42:508-513.

State Climate Office of North Carolina. 2010. NC CRONOS Database, Laurel Springs (NLSP). 6 Aug. 2010. <http:// 


\section{Research Reports}

www.nc-climate.ncsu.edu/cronos / ?station $=\mathrm{NLSP}>$.

Strik, B.C., J.R. Clark, C.E. Finn, and M.P. Banados. 2007. Worldwide blackberry production. HortTechnology 17: 205-213.

Strik, B., J.R. Clark, C. Finn, and G. Buller. 2008. Management of primo- cane-fruiting blackberry to maximize yield and extend the fruiting season. Acta Hort. $777: 423-428$.

Strik, B.C. and E. Thompson. 2009. Primocane-fruiting blackberries: Potential for extending harvest season and production regions. HortScience 44:2324.
Thompson, E., B.C. Strik, C.E. Finn, Y. Zhao, and J.R. Clark. 2009. High tunnel versus open field: Management of primocane-fruiting blackberry using pruning and tipping to increase yield and extend the fruiting season. HortScience 44: 1581-1587. 